\title{
PERUMUSAN KETENTUAN PIDANA DALAM PEMBENTUKAN PERATURAN DAERAH (Studi di Kabupaten Purbalingga)*
}

Oleh:

\author{
Muhammad Fauzan, Djumadi, dan Riris Ardhanariswari \\ Fakultas Hukum Universitas Jenderal Soedirman Purwokerto
}

\begin{abstract}
Article 143 section (2) Law Number 32 Years 2004 concerning Local Government contending that by law can load six-month coop crime threat at longest or maximun Rp. 50.000.000,00 ( fifty million rupiah). While in section (3) the law give authority to local goverment to load the crime in the out off the this regulation. This regulation by itself give authority at local government to specify crime threat or maximal penalty. Even give crime threat besides the crime serve a sentence and penalty. The Result this research that in the reality Rule of Crime in Local Regulation in Purbalingga still not yet applied the mentioned, is even found also not clear of arrangement of rule of crime in Local Regulation Sub-Province of Purbalingga, like: boundary inexistence upper and lower in rule of crime, there is no him clarity of qualifikasi glare at alternative, or cumulative or alternatif-cumulatif, there is no him rule of attempt penalization. What for the reason this research give recommendation for this local regulation.
\end{abstract}

Kata kunci: Local Government, Rule of Crime, Local Regulation

\section{A. Pendahuluan}

Sebagai sumber normatif dalam sistem pembangunan daerah, perancangan dan pelaksanaan peraturan daerah harus disusun sebaik mungkin. Perancangan dan pelaksanaan peraturan daerah harus dipandang sebagai hal dinamis untuk memberi peluang bagi pemerintah daerah yang bermaksud membangun kredibilitas negara (good governance) melalui potensinya dalam membangun daerah.

Pasal 143 ayat (2) Undang-Undang No. 32 tahun 2004 tentang Pemerintahan Daerah menetapkan bahwa peraturan daerah dapat memuat ancaman pidana kurungan paling lama enam bulan atau denda sebanyak-banyaknya Rp. 50.000.000,00 (lima puluh juta rupiah). Sedangkan dalam ayat (3) undang-undang tersebut memberikan kewenangan pada daerah untuk memuat jenis pidana di luar ketentuan tersebut. Ketentuan inii dengan sendirinya memberi kewenangan pada pemerintah daerah untuk menetapkan ancaman pidana atau denda maksimal. Bahkan memberikan ancaman pidana

\footnotetext{
* Artikel ini merupakan artikel hasil penelitian dari penelitian yang biayai Anggaran DIPA Unsoed 2008
}

lain selain pidana penjara dan denda.

Ketentuan pidana berupa denda maksimal Rp 50 juta atau kurungan selama-lamanya 6 bulan bagi setiap pelanggar perda sangat penting untuk membuat jera para pelaku tindak pidana. Sebab rendahnya ancaman sanksi pidana, terutama sanksi denda, merupakan salah satu penyebab terhambatnya upaya penegakan perda. Dengan denda yang sangat rendah orang akan dengan mudah melanggar perda.

Pada prakteknya ketentuan pidana dalam peraturan daerah umumnya menetapkan dua jenis ancaman pidana terhadap tindak pidana atas pelanggaran peraturan daerah, yaitu: pidana penjara dan/atau denda. Untuk pidana penjara juga terdapat variasi ancaman pidana: tiga dan enam bulan penjara.

Namun yang perlu dipikirkan dan dikaji adalah bagaimana menetapkan kriteria pelanggaran untuk bisa dikenakan denda atau kurungan sesuai tingkat pelanggaran itu. Sebab sangat tidak adil bila semua bentuk pelanggaran diancam pidana atau denda yang sama. Tidak mungkin pelanggaran yang dilakukan pedagang kaki lima (PKL) dikenakan pidana 
atau denda yang sama dengan pelanggaran yang dilakukan oleh penjual minuman keras. Karena itu perlu ditentukan kriteria atau tolok ukur pelanggaran sehingga layak dikenakan pidana atau denda dengan ancaman tertentu.

Di lain pihak, Pasal 143 ayat (3) juga harus dikaji lebih lanjut terkait dengan alternatif pidana selain pidana denda atau penjara dalam pelanggaran terhadap peraturan daerah serta konsekuensi yuridis yang mengikutinya. Hal ini terkait dengan makin beragamnya pelanggaran yang terjadi daerah.

Untuk itulah, penelitian ini bermaksud untuk mengkaji dan meneliti aspek hukum pidana dan pemidanaan peraturan daerah yang terdapat dalam peraturan daerah Kabupaten Purbalingga.

\section{B. Metode Penelitian}

Penelitian ini menggunakan pendekatan yuridis normatif dengan pendekatan permasalahan berupa statute approach, conceptual approach dan analytical approach. Spesifikasi penelitian ini adalah deskriptif dengan tipe penelitian berupa inventarisasi bahan hukum dan penemuan hukum. Data yang gunakan adalah data sekunder berupa sumber bahan hukum yang terdiri dari:

a. Undang-undang No. 32 tahun 2004 tentang Pemerintahan Daerah,

b. Undang-undang No 10 Tahun 2004 tentang Pembentukkan Peraturan Perundang-undangan,

c. Kitab Undang-Undang Hukum Pidana,

d. Perda Nomor 18 Tahun 1998 tentang Retribusi Izin Gangguan.

e. Perda Nomor 22 Tahun 2000 tentang Larangan, Pengawasan dan Pengendalian Minuman Beralkohol.

f. Perda Nomor 12 Tahun 2003 tentang Perubahan atas Peraturan Daerah Kabupaten Purbalingga Nomor 5 Tahun 2000 tentang Retribusi Izin Trayek.

g. Perda Nomor 20 Tahun 2003 tentang Garis Sempadan Sungai, Daerah Manfaat Sungai, Daerah Penguasaan Sungai dan Bekas Sungai.

h. Perda Nomor 4 Tahun 2005 tentang Perubahan atas Peraturan Daerah Kabupaten daerah tingkat II Purbalingga Nomor 15 Tahun 1998 tentang Retribusi Rumah Potong Hewan.

i. Perda Nomor 10 Tahun 2005 tentang Retribusi Izin Usaha Pertambangan Daerah.

j. Perda Nomor 11 Tahun 2005 tentang Retribusi Izin Lokasi.

k. Perda Nomor 12 Tahun 2005 tentang Retribusi Izin Usaha Industri dan Tanda Daftar Industri.

l. Undang-undang/Peraturan lain yang berkaitan dengan pokok permasalahan penelitian, Traktat, Yurisprudensi, Peraturan Pemerintah, Keputusan Pemerintah, dan peraturan lain yang setaraf ataupun yang berada dibawahnya.

Data yang diperoleh dianalisis dengan menggunakan analisis kualitatif.

C. Pembahasan

1. Teknis Penyusunan Ketentuan Pidana dalam Peraturan Daerah-Peraturan Daerah Di Kabupaten Purbalingga

Dalam merumuskan ketentuan Pidana, terutama dalam Peraturan Daerah, ada beberapa hal yang harus diperhatikan:

a. Rumusan pidana harus bertumpu pada asasasas umum hukum pidana. Misalnya tentang berlaku surut, percobaan melakukan kejahatan, percobaan melakukan pelanggaran dan sebagainya. Implementasi dari hal ini, adalah bahwa suatu Perda haruslah mengikuti asas-asas dalam hukum pidana. Salah satu asas adalah asas larangan retroaktif. Jika suatu peraturan perundang-undangan hendak diberlakusurutkan, ketentuan pidananya harus dikecualikan, mengingat adanya asas umum dalam Pasal 1 ayat (1) Kitab Undang-Undang Hukum Pidana yang menyatakan bahwa ketentuan pidana tidak boleh berlaku surut. Peraturan Daerah Purbalingga yang diteliti dalam penelitian ini, ternyata sama sekali tidak ada satu pun yang memberlakukan asas retroaktif. Sehingga ketentuan pidana dalam peraturan daerah-peraturan daerah yang diteliti disini, tidaklah dikecualikan dari pengaturan yang lainnya. Demikian hal-nya dengan percobaan 
melakukan kejahatan ataupun pelanggaran, ketentuan pidana yang ada dalam Peraturan Daerah Peraturan Daerah yang diteliti, tidak ada satupun yang mengatur tentang delik percobaan. Menurut peneliti, dalam Perda Nomor 22 Tahun 2000 tentang Larangan, Pengawasan dan Pengendalian Minuman Beralkohol terutama dalam Pasal 8 ayat (1) yang berbunyi:

Barang siapa melanggar ketentuan Pasal 3 dan Pasal 5 Peraturan Daerah ini, diancam pidana kurungan paling lama 6 (enam) bulan atau denda sebanyak-banyaknya Rp. $5.000 .000,00$

Dari ketentuan diatas, dapat ditambahkan ketentuan tentang hukuman percobaan, sebab essensi dari Pasal 8 ayat (1) diatas adalah larangan untuk memproduksi, memperdagangkan, mengedarkan, menyimpan, mengoplos, menjamu dan atau meminum minuman beralkohol. Kegiatan tersebut, dapat saja dilakukan dengan percobaan, misalnya: seseorang baru saja hendak mengoplos minuman keras, namun dia sudah tertangkap lebih dahulu, dengan bukti-bukti yang menunjukkan bahwa dia sedang berusaha (mencoba) mengoplos minuman keras. Apabila kemudian diatur mengenai delik percobaan dalam Pasal 8 diatas, maka dapat di tambahkan dalam ayat selanjutnya dengan ketentuan bahwa hukuman atas percobaan yang dilakukan adalah seper-tiga dari ancaman hukuman seluruhnya.

b. Dalam merumuskan ancaman pidana harus memenuhi unsur-unsur:

1) Penyebutan subyek pidana, baik yang bersifat umum (setiap orang) maupun orang tertentu atau kelompok orang tertentu (orang asing, dan lain-lain)

Dalam aplikasinya dari 8 (delapan) buah Peraturan Daerah Peraturan Daerah yang diteliti, 2 (dua) buah peraturan daerah menggunakan penyebutan subyek hukum pidana yang bersifat umum (Perda No. 22 Tahun 2000 tentang Larangan, Pengawasan, dan Pengendalian Minuman Beralkohol dan Perda No. 20 Tahun 2003 tentang Garis Sempadan Sungai, Daerah Manfaat
Sungai, Daerah Penguasaan Sungai dan Bekas Sungai) dan 6 (enam) peraturan daerah menggunakan penyebutan subyek hukum pidana yang bersifat khusus (Perda No. 18 Tahun 1998 tentang Retribusi Izin Gangguan, Perda No. 12 Tahun 2003 tentang Perubahan Atas Peraturan Daerah Kabupaten Purbalingga No. 5 tahun 2000 Tentang Retribusi Izin Trayek, Perda No. 4 Tahun 2005 tentang Prubahan Atas Peraturan Daerah No. 15 Tahun 1998 tentang Retribusi Rumah Potong Hewan, Perda No. 10 Tahun 2005 tentang Retribusi Izin Usaha Pertambangan Daerah, Perda No. 11 Tahun 2005 Tentang Retribusi Izin Lokasi, dan Perda No. 12 Tahun 2005 tentang Retribusi Izin Usaha Industri dan Tanda Daftar Industri). 7 (Tujuh) buah Perda yang menggunakan kata: "wajib retribusi" untuk penyebutan subyek hukum pidana yang bersifat khusus. Sedangkan dari 2 (dua) buah Perda yang menggunakan penyebutan subyek hukum bersifat umum, masih menggunakan katakata: "Barang Siapa". Menurut peneliti, akan lebih baik dan up to date (mengikuti perkembangan zaman) jika kata-kata tersebut diganti dengan kata-kata "Setiap orang".

2) Penyebutan sifat perbuatan pidana, apakah sengaja atau kelalaian

Dari seluruh Perda yang diteliti, tidak ada satupun yang menyebutkan sifat dari perbuatan pidana, apakah sengaja atau kah kelalaian. Menurut hemat penulis, pertimbangan sengaja ataukah kelalaian dalam pelanggaran ketentuan pidana di perda ini, di kembalikan pada institusi hakim dan pengadilan. Artinya, hakim yang nanti akan memeriksa dan mengadili yang mempunyai kewenangan menilai dan memutuskan apakah benar ada unsur kelalaian atau memang sengaja. Sehingga berat ringannya suatu hukuman, akan ditentukan dari ada atau tidaknya unsur kelalaian dan/atau kesengajaan.

3) Penyebutan perbuatan yang diancam pidana, baik dengan cara menunjuk pa- 
sal, atau pasal-pasal yang diancam pidana maupun rumusan kongrit mengenai perbuatannya

Dari 8 (delapan) Perda yang diteliti, 4 (empat) buah Perda yang dalam penyebutan perbuatan yang diancam pidana menggunakan cara menunjuk pasal dan/atau pasal-pasal yang diancam pidana (Perda No. 22 Tahun 2000 tentang Larangan, Pengawasan, dan Pengendalian Minuman Beralkohol, Perda No. 12 Tahun 2003 tentang Perubahan Atas Peraturan Daerah Kabupaten Purbalingga No. 5 tahun 2000 Tentang Retribusi Izin Trayek, Perda No. 20 Tahun 2003 tentang Garis Sempadan Sungai, Daerah Manfaat Sungai, Daerah Penguasaan Sungai dan Bekas Sungai, Perda No. 4 Tahun 2005 tentang Prubahan Atas Peraturan Daerah No. 15 Tahun 1998 tentang Retribusi Rumah Potong Hewan) sedangkan 4 (lima) buah Perda dalam penyebutan perbuatan yang diancam pidana menggunakan cara merumuskan kongkrit mengenai perbuatannya, yaitu dengan penyebutan: "wajib retribusi yang tidak melaksanakan kewajibannya, sehingga merugikan keuangan daerah". Artinya, bahwa rumusan kongkrit perbuatan pidananya adalah "merugikan keuangan daerah" (Perda No. 18 Tahun 1998 tentang Retribusi Izin Gangguan, Perda No. 10 Tahun 2005 tentang Retribusi Izin Usaha Pertambangan Daerah, Perda No. 11 Tahun 2005 Tentang Retribusi Izin Lokasi, dan Perda No. 12 Tahun 2005 tentang Retribusi Izin Usaha Industri dan Tanda Daftar Industri).

4) Penyebutan jenis perbuatan pidana apakah kejahatan ataukan pelanggaran. Penyebutan jenis pidana ini bertalian dengan sistem hukum pidana Indonesia.

Penyebutan jenis perbuatan pidana dalam Peraturan Daerah yang diteliti, masih membedakan antara tindak kejahatan (pidana) dengan pelanggaran. Ini disebabkan karena sistem hukum yang dianut Indonesia sampai dengan penelitian ini ditulis, masih mengunakan pem- bedaan antara tindak pidana dengan pelanggaran. ${ }^{1}$ Dari 8 (delapan) Perda yang diteliti, hanya 1 (satu) Perda saja yang menyebutkan bahwa perbuatan yang dilanggar termasuk kualifikasi perbuatan tindak pidana yaitu Perda Nomor 20 Tahun 2003 tentang Garis Sempadan Sungai, Daerah Manfaat Sungai, Daerah Penguasaan Sungai dan Bekas Sungai, sedangkan 7 (tujuh) Perda lainnya menyebutkan bahwa perbuatan yang dilanggar adalah termasuk kualifikasi pelanggaran.

5) Penyebutan lama atau besarnya ancaman pidana yang disebutkan adalah ancaman maksimum. Untuk pidana badan disebutkan paling lama. Sedangkan untuk pidana denda disebutkan paling banyak.

Masih adanya kerancuan dalam penyebutan ancaman maksimum dan itu terjadi dalam beberapa Perda yang diteliti. Ada 2 (dua) buah Perda yang masih mempunyai kerancuan dalam merumuskan penyebutan ancaman maksimumnya. Yaitu Perda No. 18 Tahun 1998 tentang Retribusi Izin Gangguan dan Perda No. 20 Tahun 2003 tentang Garis Sempadan Sungai, Daerah Manfaat Sungai, Daerah Penguasaan Sungai dan Bekas Sungai. Perda No. 18 Tahun 1998 memakai katakata "paling lama" untuk merumuskan denda maksimum yang harus ditanggung sedangkan Perda No. 20 Tahun 2003 menggunakan kata-kata: "setinggi-tingginya" untuk merumuskan denda maksimum. Kerancuan dalam pemakaian bahasa untuk menunjukkan ambang batas maksimum memang terlihat sepele dan ringan, namun bagaimanapun perlu kejelasan bahasa dan kesesuaian ancaman pidananya. Menurut peneliti, akan lebih tepat dan sesuai bahasa hukumnya, jika perumusan denda maksimum pada kedua Perda diatas menggunakan kata-kata "paling banyak". Ini akan lebih menunjukkan kualifikasi maksimum dari pidana

1 Kompas, 15 Juli 2006, Rapat Perdana Perumus Revisi KUHP: Implikasi KUHP Pada Perda. 
denda yang sesungguhnya. Sebab denda, yang dimanifestasikan melalui uang, secara materiil memang memiliki jumlah hitungan banyak dan sedikit.

c. Rumusan ketentuan pidana harus menyatakan secara tegas apakah pidana yang dijatuhkan bersifat kumulatif, alternatif, atau kumulatif alternatif. Hindari perumusan dalam ketentuan pidana yang tidak menunjukkan dengan jelas apakah unsurunsur perbuatan pidana bersifat kumulatif atau alternatif. Dalam bahasa perundangundangan, menentukan apakah kumultif alternatif menggunakan kata sambung "dan/atau". Jika menggunakan kata sambung "dan" berarti merupakan kumulatif, sedangkan jika menggunakan kata "atau" maka merupakan alternatif. Kerancuan dalam menentukan sifat kumulatif, alternatif atau kumulatif alternatif nampak dalam:

1) Perda Nomor 22 Tahun 2000 tentang Larangan, Pengawasan, dan Pengendalian Minuman Beralkohol, Pasal 8 ayat (1) menyebutkan bahwa:

Barang siapa melanggar ketentuan Pasal 3 dan Pasal 5 Peraturan Daerah ini...

2) Perda Nomor 12 Tahun 2003 tentang Perubahan atas Peraturan Daerah Kabupaten Purbalingga Nomor 5 Tahun 2000 Tentang Retribusi Izin Trayek, Pasal 25 menyebutkan:

Wajib Retribusi yang tidak melaksanakan kewajibannya sebagaimana dimaksud Pasal 2 dan Pasal 11 Peraturan Daerah ini...

3) Perda Nomor 20 Tahun 2003 tentang Garis Sempadan Sungai, Daerah Manfaat Sungai, Daerah Penguasaan Sungai dan Bekas Sungai, Pasal 20 ayat (1) menyebutkan:

Barangsiapa melanggar ketentuanketentuan yang tercantum dalam Pasal 10 ayat (2), Pasal 11, Pasal 13, Pasal 13 ayat (1), Pasal 15 ayat (1) dan Pasal 18 Peraturan Daerah ini...

4) Perda Nomor 4 tahun 2005 tentang Perubahan atas Peraturan Daerah Kabu- paten Daerah Tingkat II Purbalingga Nomor 15 Tahun 1998 Tentang Retribusi Rumah Potong Hewan, Pasal 23 ayat (1) menyebutkan:

Wajib Retribusi yang tidak melaksanakan kewajibannya sebagaimana dimaksud Pasal 12 ayat (1) dan (2) Peraturan Daerah ini...

Keempat Perda diatas, menunjukkan kerancuan dan ambiguitas dalam perumusan ketentuan pidana apakah merupakan alternatif, kumulatif atau alternatif kumulatif. Sebab masing-masing pasal yang dijadikan rujukan/ landasan pemidanaan, sebenarnya adalah suatu delik pidana tersendiri. Artinya masing-masing pasal sebenarnya berdiri sendiri sebagai suatu delik dimana masing-masing orang yang melanggar satu pasal tersebut, sudah bisa dikenakan pidana. Namun menjadi rancu karena dalam keempat Perda diatas, menggunakan kata "dan" yang berarti menunjukkan sifat kumulatif suatu ketentuan pidana. Logika yang timbul dari penggunaan kata "dan" adalah seseorang baru dapat dipidana jika melakukan perbuatan-perbuatan (yang lebih dari satu) tersebut, dan tidak bisa dipidana jika hanya melakukan salah satu perbuatan saja. Contoh: Pada Ketentuan Pidana Pasal 20 ayat (1) Perda Nomor 20 Tahun 2003 tentang Garis Sempadan Sungai, Daerah Manfaat Sungai, Daerah Penguasaan Sungai dan Bekas Sungai, logika yang dibangun adalah orang baru dapat dipidana berdasarkan Perda ini, jika melanggar secara kumulatif (melanggar seluruhnya) dari Pasal 10 ayat (2), Pasal 11, Pasal 13, Pasal 13 ayat (1), Pasal 15 ayat (1) dan Pasal 18. Padahal masing-masing pasal di atas, merupakan suatu delik yang berdiri sendiri, artinya setiap orang yang hanya melanggar salah satu dari pasal tersebut sudah dapat dipidana.

Maka solusi yang dapat di tempuh untuk menyempurnakan ketentuan Pidana dari keempat Perda diatas, menurut peneliti adalah dengan mengubahnya menjadi kualifikasi delik alternatif kumulatif dengan menggunakan kata dan/atau. Sehingga logika hukum yang akan terjadi dengan menggunakan kata "dan/atau" berarti bahwa seseorang dapat dipidana jika 
melanggar salah satu pasal atau tetap dapat dipidana jika melanggar lebih dari satu pasal tersebut, secara bersamaan atau terpisah. Contoh: Pada Ketentuan Pidana Pasal 20 ayat (1) Perda Nomor 20 Tahun 2003 tentang Garis Sempadan Sungai, Daerah Manfaat Sungai, Daerah Penguasaan Sungai dan Bekas Sungai, jika menggunakan kualifikasi kumulatif alternatif, maka orang yang hanya melanggar Pasal 10 akan dipidana. Begitupun orang yang melanggar Pasal 10 dan Pasal 11 yang dilakukan secara bersamaan atau terpisah waktunya, tetap dikenakan pidana.

Ketentuan kumulatif alternatif yang diterapkan bersamaan akan lebih efektif dan efisien dalam menjaring para pelanggar Perda, serta tepat dalam penggunaan bahasa hukum. Tindak Pidana dapat dilakukan oleh orang perorangan, atau oleh korporasi. Pidana terhadap tindak pidana yang dilakukan oleh korporasi dijatuhkan kepada:

a. Badan Hukum, Perseroan, Perkumpulan, atau Yayasan,

b. Mereka yang memberi perintah melakukan tindak pidana atau yang bertindak sebagai pimpinan dalam melakukan tindak pidana, atau

c. Kedua-duanya.

Ketentuan mengenai tindak pidana yang dijatuhkan kepada korporasi atau pengurus korporasi dalam Peraturan Daerah yang di teliti, hanya terdapat dalam Perda Nomor 20 Tahun 2003 tentang Garis Sempadan Sungai, Daerah Manfaat Sungai, Daerah Penguasaan Sungai dan Bekas Sungai. Ketentuan tersebut ada dalam Pasal 20 ayat (3) Perda Nomor 20 Tahun 2003 yang pada intinya mengatur bahwa ancaman pidana pada Perda ini dapat dikenakan kepada pengurus badan hukum atau badan sosial yang melakukan tindak pidana sebagaimana diatur dalam Perda No. 20 tahun 2003. Ini sesuai dengan teori fiksi badan hukum. Teori ini mengungkapkan bahwa subyek hukum sendiri dalam ilmu hukum adalah sebagai pembawa atau penyandang hak dan kewajiban dalam hubungan-hubungan hukum. Yang disebut sebagai pembawa hak dan kewajiban dapat berupa orang biasa yang disebut naturrlijke persoon (menselijk persoon), atau bukan orang biasa yang lazim disebut sebagai rechtpersoon.

Subyek hukum rechtpersoon itulah yang disebut dengan istilah badan hukum yang merupakan persona ficta atau orang yang diciptakan oleh hukum sebagi persona (orang fiktif). Pandangan tersebut dianut oleh Carl von Savigny, C.W. Opzoomer, A.N. Houwing, dan juga Langemeyer. Mereka berpendapat bahwa badan hukum adalah fiksi hukum semata, yaitu merupakan buatan hukum yang diciptakan sebagai bayangan manusia yang ditetapkan oleh hukum negara. Oleh karena itu, aliran pandangan ini disebut sebagai teori fiktif atau teori fiksi. ${ }^{2}$

Oleh karena itulah, maka dalam ketentuan Pasal 20 ayat (3) Perda No. 20 Tahun 2003, ditentukan hukuman bagi pegurus korporasi yang notabene adalah subyek hukum yang bisa dikenakan hukuman

\section{4) Sanksi Denda Ketentuan Pidana Dalam Peraturan Daerah}

Dasar pemberlakuan denda dalam ketentuan pidana di Perda-Perda dalam penelitian ini, masih mempergunakan landasan Hukum Undang-Undang Nomor 22 tahun 1999 tentang Pemerintahan Daerah, yang masih memberlakukan sanksi denda maksimumnya (setinggitingginya) adalah Rp. 5.000.000,00 (lima juta rupiah). Sementara Undang-Undang Nomor 22 tahun 1999 tentang Pemerintahan Daerah sudah digantikan dengan Undang-Undang Nomor 32 tahun 2004 tentang Pemerintahan Daerah yang dalam ketentuan Pasal 143 ayat (2) menyebutkan:

Perda dapat memuat ancaman pidana kurungan paling lama 6 (enam) bulan atau denda paling banyak Rp. 50.000 . 000,00 (Lima puluh juta rupiah)

\footnotetext{
2 R. Ali Rido, 2001, Badan Hukum Dan Kedudukan Badan Hukum Perseroan, Perkumpulan, Koperasi, Perseroan, Perkumpulan, Koperasi, Yayasan, Wakaf, Bandung: Penerbit Alumni, hlm. 7-8, Lihat Juga: CST. Kansil Dan Christine S.T. Kansil, 2002, Pokok-Pokok Badan Hukum, Jakarta: Pustaka Sinar Harapan, hlm. 14, Bandingkan Juga Dengan: Jimly Asshiddiqie, Kemerdekaan Berserikat Pembubaran Partai Politik dan Mahkamah Konstitusi, Jakarta: Konstitusi Press, Jakarta, hlm. 70.
} 
Berdasarkan ketentuan diatas, maka Peraturan Daerah Peraturan Daerah yang sudah berlaku maupun yang dibuat, ketentuan mengenai denda paling banyak (maksimum) harus mengikuti Pasal 143 ayat (2) Undang-Undang Nomor 32 tahun 2004 diatas. Bagi Peraturan Daerah yang sudah ada sebelum Undang-undang Nomor 32 tahun 2004, yang ketentuan pidananya masih mengikuti Undang-Undang Nomor 22 tahun 1999, maka ketentuan pidananya harus dirubah untuk menyesuaikan dan mengkuti ketentuan pidana sebagaimana diatur dalam Pasal 143 ayat (2) Undang-Undang Nomor 32 tahun 2004.

Sudah barang tentu bahwa perubahan besarnya denda dan hukuman dalam ketentuan pidana di peraturan daerah dari waktu kewaktu mengalami perubahan signifikan. Sebab bagaimanapun, hukum yang baik adalah hukum yang selalu mengikuti perkembangan masyarakat. Perubahan dan perkembangan masyarakat selalu bergerak dinamis. Termasuk diantaranya adalah perubahan perekonomian, inflasi, nilai tukar, harga-harga, daya beli, dan fluktuasi nilai mata uang dalam masyarakat. Oleh karena itulah maka perubahan ketentuan pidana terutama pidana denda besarnya selalu mengikuti perkembangan perekonomian dalam masyarakat. Apa yang menjadi ukuran secara materi pada masa lalu, tidak bisa dijadikan ukuran pada masa kini terlebih pada masa mendatang. Oleh karena itulah Hukum yang responsif adalah hukum yang selalu mengikuti dinamika gerak materil dari hal-hal yang ada di sekelilingnya.

Selain itu, dengan pemberian sanksi denda yang tinggi berlipat-lipat kali, tidak bisa dilepaskan dari essensi hukum untuk mengendalikan dan membuat patuh masyarakat. Sebab dengan memberikan suatu ancaman hukuman denda, yang lebih materiil, maka manusia relatif lebih akan patuh dan tunduk pada ketentuan tersebut. Karena manusia memang sering didorong oleh motif ekonomi dalam mencapai maksud-maksudnya, faktor inilah yang membuat manusia berpikir berpuluh-puluh kali sebelum melanggar suatu ketentuan. Selain itu, ketentuan hukuman denda juga selaras dan sebangun dengan maksud dari penghukuman yang sekarang lebih menitik beratkan bukan pada upaya pembalasan, namun penyadaran dan perbaikan. Uang denda yang dibayarkan tentu saja akan sangat berguna untuk merehabilitasi dan memperbaiki segala sesuatu yang rusak akibat timbulnya pelanggaran atau kejahatan tersebut. Selain juga uang denda yang dibayarkan tentu akan sangat bermanfaat bagi usaha-usaha lainnya untuk memakmurkan daerah/negara.

\section{5) Kriteria Untuk Menetapkan Ketentuan Pi- dana Dalam Perda}

Landasan Yuridis untuk mengukur lama atau besarnya pidana (pidana badan atau denda atau jenis pidana lainnya) disesuaikan dengan prinsip-prinsip sistem pemidanaan yang berlaku secara umum. Bagi peraturan perundang-undangan yang tingkatannya lebih rendah dari undang-undang, ancaman pidana, lama, dan besarnya pidana ditentukan dengan ada atau tidaknya "delegasi" dari undang-undang yang membenarkan memuat ketentuan pidana. Mengenai delegasi ini, ada yang bersifat umum atau khusus.

Umum, jika ada undang-undang yang secara umum menyatakan (misalnya) Peraturan Pemerintah dapat memuat ancaman pidana kurungan paling lama 6 bulan atau denda paling banyak Rp. 15.000.000,00.

Khusus, apabila ada undang-undang tertentu yang menyatakan (misalnya) Peraturan Pemerintah yang dibuat untuk melaksanakan undang-undang ini dapat memuat ancaman pidana paling lama 3 bulan atau denda Rp. 7.500.000, $00 .^{3}$

Maka berdasarkan penjabaran diatas, ketentuan bahwa disetiap Ketentuan Pidana di Perda harus mengikuti Pasal 143 ayat (2) Undang-undang Nomor 32 Tahun 2004 Tentang Pemerintahan Daerah adalah termasuk dalam pendelegasian yang bersifat khusus. Karena Undang-undang Nomor 32 Tahun 2004 Tentang Pemerintahan Daerah adalah termasuk undang-

\footnotetext{
3 Lihat dalam Bagir Manan, 1992, Dasar-Dasar Perundangundangan Indonesia, Jakarta Penerbit IND-HILCO, hlm. 70.
} 
undang yang bersifat khusus dan tertentu serat memang secara spesifik menyatakan dalam Pasal 143 ayat (2) agar setiap Perda mengikuti maksud dari Pasal 143 ayat (2) tersebut.

Jika optik kajian kita arahkan pada landasan Filosofis ketentuan Pidana dalam Perda yang sedang diteliti, maka ulasannya sama dengan pada saat membahas landasan filosofis pada ketentuan denda pada Perda. Bagaimanapun, suatu perundang-undangan haruslah mempunyai sifat visioner kedepan dan menjawab tantangn zaman yang bergerak maju. Salah satunya adalah dengan memberikan ketentuan Pidana yang disesuaikan. Terutama dalam hal pencantuman pidana minimal dan maksimal, sebab dengan memberi ketentuan hukuman minimal dan maksimal, maka hakim dan penegak hukum lainnya mempunyai sebuah pedoman dan patokan dalam menentukan besarnya hukuman.

Akan lebih baik jika dalam ketentuan pidana dalam Perda (maupun peraturan perundang-undangan yang lain) ketentuan pidana selain diberi batas ambang atas (maksimum) juga diberi ketentuan ambang batas bawah (minimum). Dengan begitu terdapat kesesuaian dan konsistensi hukuman yang diberikan. Seringkali kita menemukan antara ketentuan suatu ambang batas atas (maksimum) dalam perundang-udangan, sangat tidak tepat dengan implementasi keputusannya. Misalnya; ancaman hukuman pembunuhan adalah maksimal 15 tahun penjara, namun yang terjadi seringkali pelaku pembunuhan hanya dihukum 3 tahun saja. Jika saja ada ambang batas bawah (minimum), maka dapatlah dipenuhi rasa keadlian, kepastian dan konsistensi dari keputusan hukum yang bersumber dari suatu perundang-undangan.

Suatu perundang-undangan, juga harus jelas dalam menentukan besarnya sanksi hukuman pidana maupun denda. Masing-masing peraturan tersebut jelas memiliki kriteria dan hukuman yang berbeda-beda dalam penerapannya. Demikian halnya dalam Perda-Perda yang menjadi obyek penelitian ini. Masing-masing Perda haruslah mempunyai kriteria dan sanksi hukuman yang tersendiri, berdasarkan pada suatu konstruksi logika hukum yang simetris dan sebangun, sehingga konstruksinya kuat dan menjadi jelas.

Mengenai hal tersebut, Peneliti mengajukan beberapa kiteria untuk membangun sebuah konstruksi hukum yang kokoh dan responsif sehingga akan diketahui kriteria berat ringannya ketentuan pidana dalam Perda-Perda yang diteliti ini.

a. Memperhatikan kondisi daerah dan tingkat perekonomian daerah dimana Perda tersebut diterapkan, salah satu indikator dalam menentukan kriteria berat ringannya suatu ancaman Pidana dan denda yang ada dalam Perda tersebut adalah indikator dari kondisi daerah dan tingkat perekonomian daerah tersebut. Melihat kondisi Kabupaten Purbalingga yang masih dalam kategori Kabupaten berkembang, namun tingkat investasinya sudah signifikan dalam menunjang perekonomian daerah. ${ }^{4}$

b. Memperhatikan efektifitas Perda tersebut.

Efektifitas suatu Perda ataupun perundangundangan, tidak bisa dilepaskan dari faktafakta yang ada pada saat penerapan Perda atau Perundang-Undangan tersebut. Efektifitas juga sebangun dan simetris dengan keberanian dan ketegasan aparat penegak hukum (struktur), ketepatan dan kecermatan isi perundang-undangan (substansi) dan juga budaya tertib hukum dalam masyarakat dimana Perda itu diterapkan (kultur). ${ }^{5}$ Sering ditemui bahwa Peraturan perundanganundangan hanya berlaku efektif kepada masyarakat biasa, atau rakyat biasa. Sementara ketegasan penegakan hukum Perda akan melemah ketika berhadapan dengan orang atau institusi yang mempunyai kuasa, uang dan wewenang. Oleh sebab itulah, maka salah satu unsur penunjang dari efektifitas Perda itu harus di buat dengan baik, yaitu unsur dalam perumusan kaidah dan norma yang tepat sehingga substansi Perda lebih mengena dan tepat. Oleh karena itu, salah satu tonggak dan pilar dari

\footnotetext{
${ }^{4}$ Lihat lampiran hasil penelitan yang berupa gambaran umum kondisi Kabupaten Purbalingga.

5 Firedmann, Op. Cit.
} 
efektifitas Perda adalah adanya lembaga public hearing atau dengar pendapat untuk melakukan upaya-upaya agregasi kepentingan dan penyerapan aspirasi masyarakat. Pelibatan masyarakat untuk ikut serta dalam menetukan kebijakan yang akan diambil, yang notabene menyangkut hajat hidup orang bayak, adalah salah satu pilar demokratisasi dan tujuan dari adanya otonomi daerah itu sendiri. Selain sebagai sebuh keniscayaan agar Perda yang ada responsif, efektif dan mempunyai daya tolak yang rendah dari masyarakat.

c. Melihat dari jenis pelanggaran atau kejahatan dan subyek hukum yang diatur dalam Perda.

Perlu juga diperhatikan bahwa ada semacam kriteria atau alasan-alasan yang mendasari pemberlakuan jenis pelanggaran atau kejahatan dari sebuah peraturan perundangundangan. Hal ini berkaitan dengan aspek sosiologis dari peraturan perundang-undangan. Seringkali dalam memakai kriteria jenis dan beratnya sanksi pidana dan denda memakai alasan-alasan yang kabur dan tidak jelas, menjadikan perundang-undangan tidak memiliki alasan keadilaan yang dapat diterima oleh masyarakat.

Ketentuan mengenai pidana denda misalnya, seringkali ditemukan penegakan hukuman sejumlah denda tertentu dalam Perda, sejalan dan sebangun dengan penetapan hukuman kurungan/fisik, terutama dalam hal sifat alternatif suatu ketentuan pidana. Misalnya: ditemukan dalam penelitian bahwa penegakan hukuman Perda No 22 Tahun 2000 tentang Larangan, Pengawasan dan Pengendalian Minuman Keras dilakukan dengan memberikan denda sebanyak Rp. 300.000,00 (Tigaratus ribu rupiah) atau kurungan selama 1 (satu) bulan. Maksud dari hakim ketika memutuskan ini, bahwa yang umumnya dikenakan pidana akibat Perda ini adalah rakyat kecil biasa, yang memang tidak mampu. Sehingga ukuran untuk mereka adalah kurang lebih 1 bulan sama dengan Rp. 300.000,00. Atau setidak-tidaknya minimal dalam satu bulan penghasilan mereka tidaklah lebih dari Rp. 300.000,00. Yang berarti jika mereka memilih dikurung, maka sesuai dengan denda sebesar itu. Namun akan lain logikanya jika diterapkan pada produsen minuman keras yang umumnya adalah orang-orang yang mampu. Hukuman 1 (satu) bulan penjara yang jika diganti dengan denda sebanyak Rp. 300. 000,00 (tigaratus ribu rupiah) adalah sangat tidak adil bagi orang-orang yang nyata-nyata mampu. Jelas mereka akan lebih memilih membayar denda yang besarnya tidak seberapa jika dibandingkan kekayaan atau penghasilan mereka. Demikian halnya yang terjadi pada Perda-Perda yang mengatur tentang retribusi Industri, izin gangguan, retribusi usaha, dan lain-lain perda yang essensinya mengatur terhadap orang-orang yang "berpunya" atau mampu, bahkan diantaranya pengusaha. Ketentuan besar dan ringannya pidana kurungan dan denda pada suatu perda atau ketentuan Perundangundangan, harusnya mengacu pada subyek hukum yang dikenakan. Apabila subyek hukum tersebut adalah masyarakat biasa, rakyat kecil yang memang tidak mampu, maka ketentuan Pidananya juga harus responsif, simetris dan sebangun dengan kemampuan dari subyek hukum Perda tersebut. Namun jika subyek hukumnya adalah perusahaan, coorporate dan pengusaha atau orang-orang yang memang mampu, maka ketentuan pidana dalam perda atau perundang-undangan juga harus simetris dan sebangun dengan kemampuan subyek hukumnya juga. Disinilah rasa keadilan dalam perda dan perundang-undangan akan sejalan dengan kemanfaatan dan kepastian hukumnya. Demikian halnya dengan perdaperda yang berkaitan dengan pengelolaan lingkungan hidup dan kelestarian lingkungan yang sering dianggap sebelah mata dan diremehkan. Padahal essensi utama dari perda tersebut jauh lebih besar dan sangat signifikan manfaatnya. Namun perda yang menyangkut lingkungan hidup dan kelestarian lingkungan seringkali ketentuan pidananya rendah dan tidak mempunyai 
peran yang signifikan untuk mengembalikan kondisi lingkungan yang sudah terlanjur rusak. Padahal negara dan daerah akan sangat dirugikan jika terjadi kerusakan lingkungan atau pencemaran lingkungan. Banjir, longsor, kebakaran hutan, pemanasan global kekurangan air tanah, sebenarnya jika dikaji merupakan hasil dari ulah tangan-tangan jahil manusia yang tidak peduli akan lingkungan. Oleh karena itulah, negara harus mempunyai kewajiban untuk mengendalikan dampak-dampak lingkungan yang timbul akibat ulah manusia melaui instrumen hukum seperti Perda. Oleh karena itu upaya ini harus sejalan dan sebangun dengan pemberian sanksi hukuman yang relatif berat dan memberi efek jera selain efek penyadaran akan pentingnya menjaga kelestarian lingkungan hidup.

\section{Penutup}

\section{Simpulan}

Dari penelitian terhadap ketentuan pidana dalam Peraturan Daerah Kabupaten Purbalingga, dapat ditarik kesimpulan:

a. Secara keseluruhan, belum ada kriteria yang jelas, tepat dan responsif yang mengandung unsur filosofis, sosiologis dan yuridis dalam perumusan ketentuan pidana dalam peraturan daerah kabupaten Purbalingga. Kriteria dari ketentuan pidana biasanya hanya mengikuti politik hukum daerah/kabupaten dimana Perda tersebut berada.

b. Ketentuan Pidana dalam Peraturan Daerah, harus secara tegas menyebutkan subyek hukum yang dituju,

c. Masih terdapatnya perbedaan antara tindak pidana dan pelanggaran dalam sistem pidana Indonesia yang berdasarkan pada KUHP, membuat kualifikasi perbuatan dalam Peraturan Daerah terbagi menjadi dua yaitu tindak pidana dan pelanggaran,

d. Belum adanya kejelasan dalam menentukan kualifikasi delik alternatif atau kumulatif atau alternatif kumulatif dalam ketentuan pidana peraturan daerah di kabupaten Purbalingga,

e. Perumusan jumlah atau banyaknya masa hukuman, baik itu denda maupun kurungan, dalam ketentuan pidana peraturan daerah di Kabupaten Purbalingga, ternyata tidak jelas dan memakai bahasa hukum yang tidak tegas.

f. Belum dicantumkannya batas atas dan batas bawah dalam perumusan ancaman hukuman kurungan dalam ketentuan pidana peraturan daerah di kabupaten Purbalingga,

g. Belum adanya ketentuan hukuman percobaan terhadap suatu kejahatan yang memang memungkinkan terjadinya percobaan dalam tindak kejahatan dalam ketentuan pidana peraturan daerah di kabupaten Purbalingga,

h. Tujuan dari lembaga ganti rugi berupa denda adalah untuk mengembalikan segala kerugian yang timbul dari kejahatan masa lalu yang pernah terjadi. Penetapan ganti rugi melihat secara proporsional dan mendasarkan pada kemanfaatan, selain juga kepastian hukum dan keadilan,

i. Indikator dan faktor yang mempengaruhi besaran ketentuan kurungan dan denda dalam peraturan daerah adalah sebagai berikut:

1) delegasi dari peraturan perundang-undangan yang lebih tinggi,

2) memperhatikan kondisi daerah dan tingkat perekonomian daerah dimana perda tersebut diterapkan,

3) memperhatikan efektifitas Perda tersebut,

4) melihat jenis ancaman pelanggaran atau kejahatan dan subyek hukum yang diatur dalam Perda.

\section{Rekomendasi}

a. Dalam merumuskan ketentuan pidana harus jelas, apakah termasuk kualifikasi delik kumulatif, alternatif atau kumulatif-alternatif.

b. Dalam menentukan rumusan jumlah atau banyaknya masa hukuman, baik itu denda maupun kurungan memiliki reasoning (alasan) yang harus bisa dipertanggungjawabkan. Selain itu perumusannya haruslah jelas dan memakai bahasa hukum yang tegas. 
c. Dalam beberapa ketentuan pidana yang memang memungkinkan terjadinya percobaan terhadap suatu kejahatan, maka haruslah dirumuskan suatu ketentuan tentang hukuman bagi percobaan tindak pidana tersebut, yang mana ketentuannya mengikuti peraturan dan doktrin yang berlaku,

d. Ketentuan besaran hukuman kurungan dan denda dalam Peraturan Daerah, secara teknis harus menutup celah distorsi dalam penegakan hukum dan memenuhi rasa keadilan masyarakat, oleh karena itu, perlu diterapkan batas atas dan batas bawah untuk menentukan besaran hukuman kurungan dan denda.

e. Responsifitas dan ketegasan dalam perumusan ketentuan hukuman kurungan dan denda harus berimbang, simetris dan sebangun, dengan melihat faktor-faktor dan indikator yang mempengaruhinya. Implementasinya adalah dengan merumuskan kembali batas bawah yang responsif dan batas atas yang lebih tegas. Dengan demikian, diharapkan ketentuan pidana selain menjamin kepastian hukum juga memberikan keadilan dengan tetap memperhatikan faktor-faktor dan indikator yang mempengaruhi besaran ketentuan kurungan dan denda dalam ketentuan pidana peraturan daerah di kabupaten Purbalingga,

f. Rasa keadilan masyarakat dengan kepastian hukum dan kemanfaatan Peraturan daerah haruslah saling bersinergi dan saling mendukung. Ketiganya harus berjalan seiringan dan tidak terpisah-pisah, sehingga Perda memiliki responsifitas yang baik dan visioner (mempunyai pandangan kedepan), sehingga selalu mengikuti perkembangan zaman.

\section{Daftar Pustaka}

\section{Buku Literatur}

Ali Rido, R. 2001. Badan Hukum Dan Kedudukan Badan Hukum Perseroan, Perkumpulan, Koperasi, Perseroan, Perkumpulan, Koperasi, Yayasan, Wakaf. Bandung: Penerbit Alumni;
2004. Konstitusi dan Konstitusionalisme Indonesia. Jakarta: Mahkamah Konstitusi dan Pusat Studi HTN FH UI;

Bentham, Jeremy. 2006. Teori Perundang-undangan: Prinsip-prinsip Legislasi, Hukum Perdata dan Hukum Pidana. Jakarta: Nuansa;

CST. Kansil Dan Christine S.T. Kansil. 2002. Pokok-Pokok Badan Hukum. Jakarta: Pustaka Sinar Harapan;

Freidmann, W. 1967. Legal Theory, New York: Colombia University Press;

Hamzah, Andi dan Siti Rahayu. 1993. Suatu Tinjauan Ringkas tentang Sistem Pemidanaan di Indonesia. Jakarta: PT Rineka Cipta; 1994. Asas-Asas Hukum Pidana, Jakarta: PT Rineka Cipta.

\section{Artikel dan Berita Media}

Kompas, 15 Juli 2006, Rapat Perdana Perumus Revisi KUHP: Implikasi KUHP Pada Perda

\section{Peraturan Perundang-Undangan}

Undang-undang Nomor 10 Tahun 2004 tentang Pembentukan Peraturan Perundang-undangan

Undang-undang No. 32 tahun 2004 tentang Pemerintahan Daerah,

Kitab Undang-Undang Hukum Pidana

Perda Nomor 18 Tahun 1998 tentang Retribusi Izin Gangguan

Perda Nomor 22 Tahun 2000 tentang Larangan, Pengawasan dan Pengendalian Minuman Beralkohol

Perda Nomor 12 Tahun 2003 tentang Perubahan atas Peraturan Daerah Kabupaten Purbalingga Nomor 5 Tahun 2000 tentang Retribusi Izin Trayek

Perda Nomor 20 Tahun 2003 tentang Garis Sempadan Sungai, Daerah Manfaat Sungai, Daerah Penguasaan Sungai dan Bekas Sungai

Perda Nomor 4 Tahun 2005 tentang Perubahan atas Peraturan Daerah Kabupaten daerah tingkat II Purbalingga Nomor 15 Tahun 1998 tentang Retribusi Rumah Potong Hewan 
Perda Nomor 10 Tahun 2005 tentang Retribusi Izin Usaha Pertambangan Daerah

Perda Nomor 11 Tahun 2005 tentang Retribusi Izin Lokasi
Perda Nomor 12 Tahun 2005 tentang Retribusi Izin Usaha Industri dan Tanda Daftar Industri 